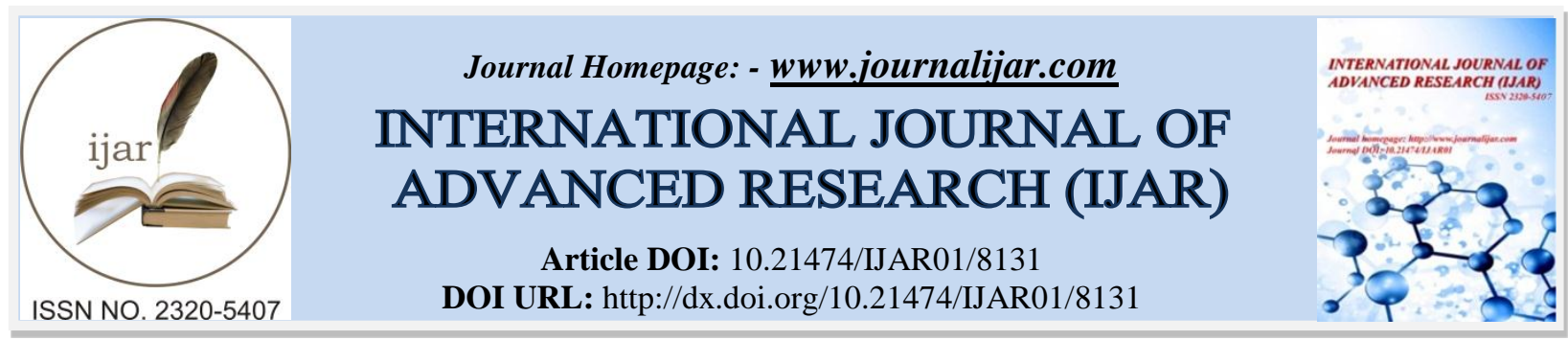

RESEARCH ARTICLE

\title{
LOCAL CONTENT INITIATIVES AND LOCAL DEVELOPMENT: THE TRENDS AND CONSTRAINTS OF THE MINING SECTOR IN CAMEROON.
}

\author{
Akama Samuel Penda ${ }^{1}$ And Bande Gulbert Mbah Tarh ${ }^{2}$. \\ 1. Ph.D. in Law, Senior Lecturer, Head of Department of English Law, FSJP, University of Maroua. \\ 2. Ph.D. in Law, Lecturer, FSJP, University of Maroua.
}

\section{Manuscript Info}

Manuscript History

Received: 01 October 2018

Final Accepted: 03 November 2018

Published: December 2018

\section{Keywords:}

Local Content, Mining Sector, Local

Development, Initiatives, Cameroon.

\section{Abstract}

Unequivocally, the paper seeks to provide a periscopic view of the designs and interventions of local content Initiatives (LCIs) in the mining sector. Indeed, from the review and analysis, the research finds that resource-rich countries are increasingly inserting requirements for LCIs into their legal framework, through legislation, regulations, contracts, and bidding practices. With LCIs requiring investors to meet certain social investment targets amidst trade-offs. Besides, it equally discovers that the local communities where the exploitation is taking place, do not always benefit from these LCIs, through job creation, local business development, capacity building and technology transfer. In this perspective, the research does reveal that there is a paramount need to frame appropriate, qualified, quantified, adapted and collaborative local content frameworks - while considering the tradeoffs of the level and type of tax concessions to be offered to the mining companies and the level of royalties, local content and social investment commitments to be bestowed on the companies. In this same token, the paper provides an assessment of the conceptual framework of LCIs with reference to local employment, training, procurement, technology transfer, local content plans as well as local ownership, with particular focus on the mining sector of Cameroon. The findings of the research are aimed to motivate policy makers and practitioners in the mining sector to rethink and introduce specific legislation, policy and model contracts on local content, as a vital first step towards operationalizing LCIs, as a sustainable and alternative strategy to avoid the resource curse trend. Similarly, scholars from academia, civil society organisations, think tanks and other research institutions will find the research outputs a valuable addition to their current knowledge on the mining sector and an impetus to conduct more research on local content in general.

Copy Right, IJAR, 2018,. All rights reserved.
Corresponding Author:-Akama Samuel Penda. Address:- Ph.D. in Law, Senior Lecturer, Head of Department of English Law, FSJP, University of Maroua. 


\section{Introduction:-}

In this contemporary era, local content is receiving enormous attention in resource rich developing countries, with an increasing number of countries introducing or reinforcing local content with a view to stimulate the use of local factors of production to create value in the domestic economy and hence expand their industrial sectors. Explicitly, Local Content Initiatives (LCIs) and legislation typically require investors to purchase a certain percentage of goods and services within the host country, and to train and hire national staff. ${ }^{1}$ Indeed, in Sub-Saharan Africa, at least 11 countries have recently formulated local content policies for their oil and gas industries, or are in the process of doing so. ${ }^{2}$ The main goal of LCIs is to increase the economic benefits from natural resource extraction. In this perspective, it can be highlighted that in the African context, local content is envisaged as a potential solution to the sky-high rates of unemployment among the youth on the continent, and as a possible means to reduce social unrest and violence and contribute to the industrialisation of resource rich countries. ${ }^{3}$ Nonetheless, it is worth noting that many scholars have emphasised the potential negative consequences of local content polices in countries with flawed institutions, specifically those characterised by rent seeking behaviour and patronage. ${ }^{4}$ Similarly, there are also concerns that strong and binding regulations for local content may limit the companies' ability to generate income and thus host countries' revenues from the sector. ${ }^{5}$ Besides, it is realised that in some cases, these LCIs are designed for a clearly identified target group in spatial, industrial or social terms, while in other cases, they are part of a strategy to fundamentally transform the local economy, thus in such cases, it is expected that new productive activities arising directly and indirectly from the activities will make sustainable contributions to employment and income generation in the long run. ${ }^{6}$

In this regard, this paper seeks to assess how a viable LCI framework can be design and implemented within the mining sectors, that could greatly enhance the economic sustainability of the producing communities in general with particular focus on Cameroon. It equally aims to answer the question: 'Can the national and local governments, companies, industries, civil society organizations (CSOs) ${ }^{7}$ and the indigenous communities, maximize local benefits through partnerships agreements amongst them? From this, it is worth accentuating that in all cases, the governments need to set the pace with clear targets from which companies should make firmed commitments and also publish transparent reports on the results. Such endeavours will enable CSOs to be able to analyse the results and monitor progress of LCIs. In sum, the paper is organised in three sections, with the first section providing the conceptual framework and contours of LCIs, while the second section considers the design and various types of interventions in LCIs, and the third section evaluates in a specific context the issues of local content under the mining legal framework of Cameroon, by highlighting its applications and constraints, as observed in the Mobilong Diamond Project. With the aimed to put forth, some viable recommendations that will aid in boosting the recognition and application of local content in other sectors. The analysis identifies specific types of strategy to promote LCIs, such as, promotion of local employment, skills development for nationals and national industry

${ }^{1}$ Langea, S. and Kinyondo, A. Resource nationalism and local content in Tanzania: Experiences from mining and consequences for the petroleum sector, The Extractive Industries and Society 3, 2016, 1095-1104.

${ }^{2}$ Ovadia, J., The dual nature of local content in Angola's oil and gas industry: development vs. elite accumulation. J. Contemp. Afr. Stud. 30 (3), 2012, 395-417; Ovadia, J., Local content and natural resource governance: the cases of Angola and Nigeria. Extr. Ind. Soc. 1 (2), 2014, 137-146; Ablo, A., Local content and participation in Ghana's oil and gas industry: can enterprise development make a difference? Extr. Ind. Soc. 2 (2), 2015, 320-327.

${ }^{3}$ Ovadia (2012)., op cit. 139.

${ }^{4}$ Wiig, A., Kolstad, I. Multinational corporations and host country institutions: a case study of CSR activities in Angola. Int. Bus. Rev. 19 (2),2010, 178-190; Oguine, I. Nigerian content in the nigerian petroleum industry: legal and policy issues. J. Energy Nat. Resour. Law 29 (4), 2011, 405-430.Oguine, 2011; Ovadia (2014)., op cit.; Hansen, M.W., Buur, L., et al., 2016. The economics and politics of local content in african extractives: lessons from Tanzania, Uganda and Mozambique. Forum Dev. Stud. 43 (2), 201-228.

5 Kolstad, I., Kinyondo, A. Alternatives to Local Content Working Paper 2015/106. United Nations University (UNU) - World Institute for Development Economics Research (WIDER), Helsinki. 2015.

${ }^{6}$ Ramdoo, I. Local content policies in mineral-rich countries. An overview. ECDPM Discussion Paper No. 193, 2016, p. v.

${ }^{7}$ CSOs are defined in this context as organized, independent (preferably politically non-aligned) groups that have an externally focused role in facilitating communication among the community, industry and government, conducting independent research and oversight, disseminating results and advocating for necessary change. This includes NGOs (international or national), industry bodies (business chambers) and the media. Many of the roles CSOs play require supplementary funding support, because typically their own operational budgets are meager. 
participation. This is achieved by sourcing information from existing policy documents, legislation, contracts, data from enterprise centres and reports from governments and international mining companies. Most pertinently, the paper ends with a conclusion highlighting the various elements necessary to have a viable and successful local content framework in the mining sector, through the building of solid partnerships and joint responsibility in enhancing the compliance and implementation of LCIs.

\section{Conceptual Framework of Local Content Initiatives}

Although there is no agreed definition of local content, Warner defines it in terms of the value contributed to the national economy through the purchase of national goods and services. ${ }^{8}$ In the same token, Esteves, Coyne and Moreno, stipulate that it includes various schemes ranging from delivery of raw materials on site, to establishment of commercial relations with firms with permanent operational offices in a given area. ${ }^{9}$ In this regard, they assert that local content policies in the context of the hydrocarbon sector are aimed at extending or expanding the benefits of the oil, gas and mining activities for the national economy; ${ }^{10}$ with the policies attempting to open access to economic opportunities through employment, participation in the supply chains or provision of other related support services. ${ }^{11}$ Conversely, according to Bacon, Tordo and Anouti, local content policies are not only related to the immediate increase in local services or products, but also to actions that will result in improvements and long-term growth in other sectors related to the hydrocarbon industry. ${ }^{12}$ More so, even though they have emphasized that local content be referred to jobs or value added created anywhere in the domestic economy as a result of the actions of oil companies, as well as the jobs created in localities adjacent to the oil and gas production plants; however, it is noted that most of the policies do not specifically refer to localization of local content in the economy, thus, it is common for communities near the production facilities - possibly the most affected - to exert greater pressure for job creation. ${ }^{13}$ Similarly, Perez, asserts that the aim of local content policies is to make the participation of countries in globalized industries as broad as possible in terms of value added, which means that the incentives for local content may range from interest rate subsidies in favour of strategic sectors and projects, to contractual obligations in the public market. He notes that foreign companies must be seen as partners in the implementation of local content policies, because they are the starting point for generating economic and technological chains which open access to larger segments of the global production chains. ${ }^{14}$ In this perspective, policymakers of resource-rich countries can stimulate economic development through LCIs at the local level by identifying key sectors with higher-than-average backward and forward links compared with other sectors in the local region.

Explicitly, it is worth noting that a scan of the economic development trajectory of resource-rich countries suggests that many have not managed to derive sufficient economic and political benefits from their natural resources. In this regard, numerous studies ${ }^{5}$ indicate that extractive resources can potentially become a 'curse' 16 , if not managed well, although evidence is non-conclusive regarding the correlation between resource endowments and economic outcomes. More so, many countries that became excessively dependent on mineral exports often did so at the expense of their other economic sectors and in particular their industrial sectors, leaving very concentrated economic

\footnotetext{
${ }^{8}$ Warner, M. Local Content Solutions: Participation of Domestic Industry in Procurement for Oil, Gas a Mining Projects, Sheffield, England: Greenleaf Publishing, 2011.

${ }^{9}$ Esteves, A., Coyne, B., Moreno, A. Iniciativas sobre contenido local: mejorar los beneficios subnacionales de los sectores petrolero, gasífero y minero. Nueva York: Revenue Watch Institute. 2013.

${ }^{10}$ Ibid.

11 Ibid.

${ }^{12}$ Bacon, R., Tordo, S. and Anouti, Y. Defining Local Content. Local Content Policies in the Oil and Gas Sector. Washington, D.C.: World Bank. 2013.

${ }^{13}$ Bacon, Tordo and Anouti (2013)., op cit.

${ }^{14}$ Pérez, A. Inversión extranjera sí, pero con contenido local: estrategias de desarrollo en Brasil (DT). Working document 7/2012. Madrid: Real Instituto Elcano, Cooperación Internacional y Desarrollo, Latin America. 2012.

${ }^{15}$ For a recent review of the academic literature, see Ploeg, F. van der. "Natural resources: Curse or blessing?" Journal of Economic Literature, volume 49, number 2. 2011.

${ }^{16}$ See Auty. R. Sustaining development in mineral economies: The resource curse thesis. Routledge.1993; Sachs J. D and Warner A. M. Natural resource abundance and economic growth. in Leading issues in economic development, G. Meier and J. Rauch, eds., Oxford University Press, 1995 and revised 1997; Ramdoo. I. Fixing Broken Links. Linking Extractive Sectors to Productive Value Chains. Discussion Paper 143. ECDPM. Maastricht: 2013; Stevens P., G. Lahn and J. Kooroshy. The Resource Curse Revisited. Research Paper. Energy, Environment and Resources. Chatham House. London. 2015.
} 
structures highly vulnerable to the volatility of commodity prices or currency appreciation ${ }^{17}$. Correspondingly, experiences across resource-rich countries globally suggest that the countries have even embraced different routes at different moments of their development trajectories. These were defined by these countries' internal systemic and political realities as well as exogenous contextual situations, such as the cyclical behaviour of commodity prices, demand and supply and technological changes. Amongst others, it is realised that one of the key policy instruments commonly aimed at stimulating resource-based economic transformation is local content. For example, with regards to employment, local content policies seek to secure an immediate increase in the share of local employees. These policies can also go as far as imposing a legal requirement onto extractive companies to actively recruit the local workforce in such a way as to create jobs or facilitate the transfer of valuable skills and knowledge from foreign labour to the local workforce. For these reasons, resource-rich countries are encouraged and motivated to design and implement local content policies which are linked to economic and socio-political considerations, the balance of which is a delicate act.

On the economic front, local content is perceived as a 'low-hanging' fruit because it can potentially create jobs and stimulate local industrial development. It seeks to capitalise on the companies' necessity to source certain critical goods and services as well as on various types of jobs that are needed during the life cycle of the mine, at different skills levels. It is estimated that between 40 and 80 percent of the revenue created in oil, gas and mining is spent on the procurement of goods and services. ${ }^{18}$ With the share spent in countries varying significantly, depending on the type of mineral at stake and on the capacity of the countries to supply the requisite goods and services to the extractive firms. Similarly, it is estimated that procurement spending significantly exceeds the contribution to government revenues, which only range between $3-20$ percent of GDP. ${ }^{19}$ For this reason, more than 90 percent of resource-rich countries seek to use local content policies to get as much benefits possible from that potential. ${ }^{20}$ Furthermore, LCIs are ways of inciting the development of competencies, necessary to make the industry function. While sometimes the requisite talent or pool of expertise might not be immediately available due to skills mismatch or skills shortage, in other circumstances, extractive companies prefer to use expatriate labour. In this regard, LCIs are meant to encourage workforce development and transfer of skills and knowledge, to gradually incite companies to use more local labour and less foreign workers, in particular strategic positions. Equally, LCIs are ways to create economic linkages and business opportunities for local entrepreneurs. Besides, in certain cases, it is noted that specialised goods and services needed at various stages of the life cycle of the mine may not be available, and thus the companies may purchase such goods and services from international providers.

Aptly, on the socio-political interests, LCIs are increasingly consider as a vital tool in enhancing sustainable development. Indeed, in many resource-rich countries, societies are denouncing policy failures and are increasingly holding the governments to account because the extractive sector has largely failed to deliver on inclusive and sustainable development objectives and welfare creation. In this regard, the Africa Progress Panel 2013, for instance, portrayed the wide disconnection between wealth and well-being, depicted by the mixed record between high growth rates in some resource-rich countries and poverty and low human development. ${ }^{21}$ Thus, the complex political economy surrounding the resource sector calls for governments to navigate among the various interests to secure deals that work for companies while maintaining social peace and maximising benefits at the national level. In that sense, LCIs can provide useful tools to create the visible opportunities at the domestic level. However, making better use of extractive resources is not a challenge unique to only resource-rich developing economies, but also to resource-rich developed countries as well. It is noted that the UK or Norway governments have historically played a very pro-active role in designing solid local content policies at the early stage of development of their extractive sectors. Thus, despite their highly educated labour force with extensive technical competencies in highly specialised industries, at that time, these countries still lacked sufficient domestic oil and gas related services and industries to support the extractive sector. To address this, the UK for instance, resorted to a number of policy instruments such as discretionary licensing and strict audits of purchases by oil companies to ensure procurement from domestic

\footnotetext{
${ }^{17}$ See abundant literature on Dutch Disease, for e.g. Corden. W.M. Booming sector and Dutch disease economics: Survey and consolidation. Oxford Economic Papers, volume 36, number 3, 1984; Wheeler. D. Sources of stagnation in sub-Saharan Africa. World Development, volume1, issue 1, January 1984.

18 McKinsey Global Institute. Reversing the Curse: Maximizing the Potential of Resource-Driven Economies, December 2013.

19 ICMM. Enhancing Mining's Contribution to the Zambian Economy and Society. Mining Partnerships for Development Report. April 2014.

${ }^{20}$ See McKinsey (2013)., op cit.

${ }^{21}$ Africa Progress Panel (APP). 'Equity in Extractives. Stewarding Africa' Natural Resources for All'. Africa

Progress Report 2016. Geneva: 2013.
} 
suppliers. $^{22}$ Additionally, it strongly supported transfer of R\&D capabilities and encouraged joint ventures with domestic players to facilitate knowledge and know-how transfer. Also, in Norway, primarily through its national oil company, Statoil, the government promoted LCIs by establishing a mandatory condition upon the International Oil Companies to transfer technology and expertise to scale up local participation in the oil and gas industry. While, the UK and Norway did not impose any specific employment or local content targets or quotas, they nonetheless, emphasised value addition and the building of competencies. In this modern era, LCI in UK is estimated at around 85 percent with nearly 100 percent in post-development operations. ${ }^{23}$ While in Norway, the share of LCI has reached between 50 and 60 percent for investments in the development of new petroleum fields and exceeds 80 percent for maintenance and operations. ${ }^{24}$

\section{Designs and Interventions of Local Content}

While the policy orientation regarding LCIs is usually set by governments, in practice these policies are designed and implemented by a range of other actors. For instance, it is not rare to find mining companies driving their own LCIs because it makes business sense to do so, or because it is important to secure a social licence to operate ${ }^{25}$. Similarly, at the level of local communities, specific community development agreements increasingly include local content provisions to prevent risks of conflict or to ensure economic benefits trickle down to the local population. From these perspectives, this section readily highlights the main types of interventions by the governments, industries and local communities respectively, in designing LCIs.

\section{The modalities of public interventions}

In sum, it is worth accentuating that extractive resources are public assets. Since in most countries (with the exception of the United States ${ }^{26}$ ) sub-soil assets are the property of the State. This fact is explicitly grounded in the constitutions of countries or well established in their legal frameworks. It largely explains why about 90 percent of resource-rich countries has one form of local content policies or another, although in different architectures. ${ }^{27}$ Consequently, delivering local benefits in the communities where extractive companies operate is no longer a choice, but a necessity that is increasingly mandated by law. ${ }^{28}$ In this line of thought, it is realised that governments are now implementing LCIs in two ways: On the one hand, by adopting a 'stick' or regulatory approach, where the aim is to enact and watch over the implementation of the legislation and policy instruments, to which companies must comply. In this case, the measures enacted are generally mandatory in nature and have a strong compliance mechanism which, if not respected, can lead to severe financial sanctions or loss of licenses in extreme cases. One the other hand, by taking a 'carrot' or incentive-based approach, whereby the State acts as a facilitator, and instead, provides various forms of incentives to companies on the condition that the latter use local factors of production. These can take the form of fiscal incentives offered to companies for the establishment of facilities to locally manufacture goods or provide services which would otherwise be imported, tariff exemptions or duty drawbacks for companies who will use local suppliers, or concessionary interest rates on loans provided to local suppliers. However, in practice, many countries implement a mix of both types of policy approaches, the balance being defined by:

Firstly, the level of economic development, maturity of the industry or the level of dependency on resources. In this regard, more advanced economies tend to move away from strict regulatory frameworks, towards softer policy instruments, which are based on financial and/or fiscal incentives and subsidies linked to existing and functional institutions. For instance, in the early 1970s, when Norway had a nascent hydrocarbon industry, it designed policies that were more regulatory in nature to stimulate local procurement and value addition. In particular, it used the grant

${ }^{22}$ Wallace A. 'Understanding Local Content Policies in Africa's Petroleum Sector'. Published in the

National Law Review. May 2016.

${ }^{23}$ Ibid.

${ }^{24}$ Heum, P. Local Content Development - Experiences from Oil and Gas Activities in Norway. SNF Working Paper No. 02/08. Institute for Research in Economics and Business Administration. Bergen: 2008.

${ }^{25}$ See Tamasang, C. Unveiling Local Content Provisions in Extractive Sector Laws in Cameroon: Perspectives for Sustainability of National Livelihoods. African Journal of Law, l'Harmattan, Paris, N ${ }^{\circ}$ 1/2016, p. 11.

${ }^{26}$ In the US, only resources off shore and on federal lands such as national parks are controlled by the national government. Other subsoil mineral rights may belong to individual states or to private property owners. Minerals on Native American lands are subject to special rules.

${ }^{27}$ See McKinsey (2013)., op cit.

${ }^{28}$ See Dashaco, J. and Bande, G. Social Licence and its Bearing in Cameroon, African Journal of Law, Numero Special, 1'Harmattan, Paris, 2015, pp. 75-118, for a detailed understanding of the concept of social licence. 
of licenses, along with additional agreements targeting training of Norwegian nationals and technology transfer arrangements to ensure local content. ${ }^{29}$ As the country joined the European Economic Area in 1994, as the industry evolved, the Norwegian government eased its policy mix.

Secondly, the degree of success or failures of previous attempts in stimulating better use of local factors of production. For instance, in Nigeria, prior to the enactment of the Nigeria Local Content Development Act, LCIs were negotiated in individual contracts. However, these were rarely implemented by international extractives companies, because they lacked the force of law and therefore had no penalty for non-compliance. With the introduction of the local content laws, with appropriate sanctions, it is observed that the level of compliance has improved, assuming a more positive impact on local content uptake (although this does not guarantee the effectiveness of the policies). Consequently, to stimulate LCIs, the public interventions usually take two forms ${ }^{30}$ : on the one hand, they are 'mandatory in nature', with the companies having a legal obligation to meet certain requirements, as required by specific legal frameworks or contractual agreements; with the mandatory requirements taking the form of quantitative targets, in terms of volume (such as the number of local staff to be employed or number of contracts to be awarded to local suppliers) or value (that is, the percentage of spending on local procurement). Alternatively, they can be qualitative in nature, such as an obligation to report or justify hiring foreign labour or sourcing inputs from abroad (as in the case in Australia) or to give preferential treatment to local suppliers or labour force. Although no numerical targets are specified, companies are nonetheless obliged to abide by the requirements, pending sanctions for non-compliance. ${ }^{31}$ While on the other hand, they are 'voluntary in nature', with the companies generally agreeing to support the local content policy objectives set by governments, based on their own terms and conditional upon the fact that those policies do not have a negative effect on the competitiveness of the industries. Pertinently, it is observed that these policies work best in countries where the institutions are strong, the economic structure is more diversified, the local suppliers are available and the workforce has the capacity to take up opportunities. In this situation, it is realised that the companies may agree to unbundle their procurement requirements, publish their procurement needs, vacancy notices and share as much information as is necessary to support local participation.

\section{The horizon of private sector interventions}

Explicitly, while the role of the governments is to set the framework for LCIs, in practice, the drive to implement these LCIs must come from the industry itself. While some mining companies do the minimum to apply the rules, others are much more proactive and take their own initiative to seek local and innovative solutions to source their procurement needs. They acknowledge the business benefits that they can derive from providing suppliers' opportunities to local communities and local enterprises. These initiatives are motivated by two vital factors: the supply chain development and support to workforce productivity. As with the first factor, 'supply chain development', experience has shown that many companies are moving away from the old paradigm where local content is viewed with a compliance mind-set and hence do the strict minimum to meet regulatory requirements, while not committing to engage their core business operations. In such a case, the interaction with the local community is viewed purely as a risk management strategy. Today, as more countries have raised the bar regarding increasing benefits at the local level, firms are shifting their approach to extract business opportunities of mutual benefit. To that effect, many mining companies are integrating local supply chains support in their procurement sourcing policies as a cost-effectiveness or savings strategy. These include a focus on core inputs from local businesses, when the latter can supply quality, timely and competitive products. Support also sometimes includes accompanying measures for suppliers or local employees to meet the standards and requirements of companies. To

\footnotetext{
${ }^{29}$ Columbia Centre on Sustainable International Investment (CCSI), Capturing the benefits of a transfer of mineral rights - scenarios to capture by contract/legislation/regulation and issues to consider: 2016.

${ }^{30}$ For a more detailed analysis, see Ramdoo, I. Local content policies in mineral-rich countries. An overview. ECDPM Discussion Paper No. 193, 2016, p. v.

${ }^{31}$ LCIs can be found in: Primary legislations, which are enacted in Acts of Parliaments and statutes. Examples include Nigeria's Oil and Gas Industry Content Development Act 2010; Ghana's Petroleum (Local Content and Local Participation) Regulation of 2013; or Mozambican Petroleum Law issued on 18 August 2014; Secondary legislations, which are delegated legislations emanating from primary legislations. Examples include ministerial orders like those approved in Angola aimed at imposing specific local content obligations on companies carrying out oil and gas activities in the country.
} 
achieve this objective, many mining companies are building strong partnerships with local businesses by aligning common interests or joining forces with other mining companies to tap onto economies of scale and to maximise mutual benefits from developing the local supply chain and sharing knowledge with local firms. Also, these can take the form of private-public partnerships, where industries work with government institutions to find and support business solutions for some critical operations. ${ }^{32}$

While for the second factor, 'support to workforce productivity', the mining sector is known to be capital intensive, except during the construction phase where temporary and unskilled labour is in high demand. During the production phase, however, most labour requirements for core activities are highly skilled and quite technical in nature. Thus, in many resource-rich countries, these types of labour are not always readily available locally. Companies, therefore, must have recourse to foreign labour to fill in the gaps. This can cause serious tensions with the local population, especially if the rate of unemployment is high in the affected community. In response to this, as a way to improve their local footprint regarding local labour, many mining companies have chosen to reinforce their workers' skills and capabilities and provide training opportunities for the local population. It is a strategic concern because it can significantly scale up the productivity of the workers and companies, but also a developmental one because it can enable the local population to develop their capacities and seize employment opportunities in the mining industry and raise their incomes. The efforts to support the productivity of workers include: identifying the skills gap with a view to support local initiatives to close the supply deficit; financial support to local training and vocational institutions; providing scholarships and bursaries to students; and provide continued access to training and skills development to employees, including through intra-corporate internships. ${ }^{33}$ If these are appropriately done, then it is clear that extractive companies can have greater impact on the development and employment of suppliers and on cost-savings by developing inclusive business models, which unfortunately, these types of models are not sufficiently widespread across the industry as may be possible and desirable.

\section{The pertinence of working with local communities}

As highlighted above, local content can be a strategic contributory factor in securing a social license to operate and hence leaving a positive legacy in countries beyond the life cycle of the mine. In this sense, supporting development projects that are important for the well-being of the communities can significantly reduce the social risks of the extractive projects. Repeated tensions and conflicts with local communities have prompted mining companies and governments to develop some forms of structured engagement with the communities that live around their mines. This approach takes a slightly different slant in the sense that it seeks to mitigate or offset the effects of the extractive activities on the livelihoods of the communities rather than create value in the first place. The approach is more targeted than that taken by governments for instance, as they are geared towards a defined population, that generally live in a short distance from the mine. ${ }^{34}$ Consequently, while there is no standard model for these arrangements, genuine partnerships aimed at developing more sustainable and mutually beneficial relationships have evolved in particular contexts and often on an ad-hoc basis, although those are becoming increasingly popular. For this reason, there are wide disparities in approaches across countries and companies as well as in the scope and depth of those partnerships or community development agreements. The drive for community development agreements can come from the Government, the mining companies or from the communities themselves.

On the one side, the governments may impose a legal obligation to 'consult' the local or indigenous communities before a company starts a project. ${ }^{35}$ These consultations generally give rise to community agreements that have a

\footnotetext{
${ }^{32}$ Vale. Sustainability Report. Rio de Janeiro. 2007; Shared Value Initiative. Extracting with Purpose. Creating Shared Value in the Oil and Gas and Mining Sectors' Companies and Communities. FSG Reimaging Social Change. Shared Value Initiative, 2014.

${ }^{33}$ World Gold Council. 2014. Responsible Gold Mining and Value Distribution, A Global Assessment of the Economic Value Created and Distributed by Members of the World Gold Council, October 2014.

${ }^{34}$ Dupuy, K. Community Development Requirements in Mining Laws. Global Dataset. Created by Kendra Dupuy $\mathrm{PhD}$ Candidate, University of Washington Department of Political Science, Seattle, USA \& Natural Resource Management Advisor, U4 Anticorruption Center, Chr. Michelsen Institute, Bergen, Norway: 2014.

${ }^{35}$ This can be appreciated in the case of Canada, for example. Its 1982 Constitution Act recognised and affirmed the existing Aboriginal and treaty rights of the Aboriginal peoples of Canada, which included the First Nations (Indian), Inuit and Metis people of Canada. Thus, the federal and provincial governments have a general duty to consult any
} 
long-term objective to ensure and maintain the dialogue process between the mine and the communities. On the other side, when driven by companies, community development agreements aim at minimising the risk of potential tension or addressing the effects of a conflict with the local community. The purpose is to manage the reputational risk of the company and hence secure a social license to operate. These forms of agreements are of a voluntary nature but comprise of commitments, which companies generally respect. The scope of these agreements varies significantly from country to country. They can be philanthropic or provide more sustainable economic benefits to the communities, such as local content guarantees in the form of employment or business opportunities. ${ }^{36}$

In sum, it is worth noting that within the mining sector, there are evolving commitments and attitudes toward local content. In many instances, it is observed that the initial motivating factor to invest in LCIs was based on the need to comply with the formalized commitments, either to a host government, an investment partner such as the International Finance Corporation (IFC), an indigenous community, or in pursuit of a social license to operate. In this regard, it is worth accentuating that compliance is readily deemed necessary in order to secure access to resources. Correspondingly, it is envisaged that the international or foreign good practices x-rayed above might be helpful to resource-rich developing countries, such as Cameroon, in crafting a more comprehensive, practical, reliable, sustainable, and enforceable local content framework in the mining sector in particular and other viable sectors. Similarly, it may motivate the establishment and maintenance of enduring partnerships with the local stakeholders for mutual benefit. In this perspective, the next section provides an overview of LCIs in the mining sector in Cameroon.

\section{Overview of Local Content in Cameroon's Mining Sector}

In the light of the foregoing analysis, before delving into the trends and appraisal of local content in the mining sector, it is appropriate to provide a synoptic view of the mineral potentials of Cameroon. In this regard, it is worth accentuating that Cameroon has one of the richest subsoils in sub-Saharan Africa, even though its rich potential is not yet fully developed, although there are huge mining projects underway. Actually, it is blessed with extensive bauxite reserves in Mini-Martap and Ngaoundal, which are estimated to about 1100 tons in the Adamawa region of the country. ${ }^{37}$ Equally, the country is destined to be a major iron producer and hub of the Central African iron supply chain - with the Mbalam iron ore project expected to produce about 35 million tons of iron ore per annum. The Mbalam iron ore deposit is estimated at about 2.5 billion tons at $40 \%$, while in Kribi it is estimated at about 350 million tons at $35 \% .{ }^{38}$ In the same token, Akonolinga has rutile deposits with geological reserves of about 300 million tons at $0.9 \%$, with the Mobilong diamond deposits reserves estimated at about 700 million carats discovered in 2008. Correspondingly, in 2012, Cameroon joined the Kimberly process for the certification of the Mobilong diamond, thus, paving the way for its output. Besides, limestone and marble are found in the northern part of the country with reserves of limestone deposits in Figuil estimated to about 600,000 tons and marble in Bidzar estimated to about 2,500,000 tons. ${ }^{39}$ Moreover, other limestone deposits were discovered in Moko, Mbalangi and Bogongo in the South West region, in Mintom in the South region and in the Littoral region of the country. ${ }^{40}$ In this regard, Cameroon is considered as one of most exciting mining destinations in Africa, with over 600 research and mining

Aboriginal group whose treaty rights may be affected by a governmental decision, including the grant of permits or licences relating to mining activity. The duty to consult 'arises when the Crown has knowledge, real or constructive, of the potential existence of the aboriginal right or title and contemplates conduct that might adversely affect it'.

${ }^{36}$ O'Reilly, K. and Eacott. E. 'Aboriginal People and Impact and Benefits Agreements': Report of a National Workshop, 29 - 31 May 1998 organised by the Canadian Artic Resources Committee, Yellowknife N.W.T. 1998; ISS. 2001. 'Agreements between mining companies and indigenous communities'. A Report to the Australian Minerals and Energy Environment Foundation. Report prepared by Indigenous Support Services and ACYL consulting; see Esteves et al. (2013)., op cit.

37 Mbendi. Overview of mining sector in Cameroon. 2010. www. mbendi.co.za; CAPAM. «Secteur minier Camerounais : Histoire de l'activité minière et géologique au Cameroun ». 2013. www.capam.cm; CIMEC. Cameroon International Mining Conference and Exhibition. 2013. « Responsabilité sociétale dans l'exploitation minière artisanale au Cameroun : cas du CAPAM », présentation de Essomba jean marcel, coordonateur du CAPAM durant le CIMEC. www.cimec2013.com

${ }^{38}$ Ibid.

${ }^{39}$ Ibid.

${ }^{40}$ Ibid. 
permits being granted to companies within the past years. ${ }^{41}$ Previously, however, the exploration of gold in Cameroon was carried out by the artisanal sector, but currently with the advent of the amendment of the Mining Code, major mining exploration companies are conducting gold exploration. With positive results registered in Betare Oya, Bindiba, Colomine and Ngoura in the East region, where the exploration and mining permits were granted, with a total of $447 \mathrm{~kg}$ of declared production in $2013 .{ }^{42}$

Concretely, the Mining Code as amended ${ }^{43}$ is the principal legal framework governing the mining sector in Cameroon, with its main purpose being to regulate all mining activities and promote investments in the mining sector in Cameroon. Conversely, even though the country is endowed with diverse mineral resources, unevenly distributed throughout the national territory, their exploitations and explorations are still lagging behind; especially as seen with the granting to date of only 5 exploitation permits for nickel-cobalt, diamond, limestone and marble, and 167 exploration permits ${ }^{44}$ on only $40 \%$ of the national territory. Correspondingly, the Cameroon-Korea Mining Incorporation (C\&K Mining Inc.), a Korean company established in Cameroon since 2007, was amongst the luckiest companies to be granted the exploitation permit in $2010 .{ }^{45}$ It is currently engaged in the industrial production of diamonds in the locality of Mobilong, located in Yokadouma in the Boumba and Ngoko division of the East region of Cameroon. Accordingly, ownership of C\&K Mining Inc with respect to shareholding is as follow: 10\% by the Support Unit for Promotion of Artisanal Mining (CAPAM), $10 \%$ by the State of Cameroon ${ }^{46}, 10 \%$ by Cameroonian nationals and $70 \%$ by the Koreans (KOKO Enterprise Company ${ }^{47}$ ). From this, it is worth noting that the $10 \%$ state participation is free of charge as set out in the Mining Agreement. In sum, the permit covers about $236.25 \mathrm{Km}^{2}$ and is valid for 25 years $^{48}$ as inscribed in the special register of the Department of Mines and Geology. More so, on the financial aspect, the company plans to invest between 1 and 1.3 billion dollars in the project over a quarter century. But presently, it is still in search of potential financial partners to extend its industrial diamond production. Equally, in addition to its industrial mining title in Mobilong, the company also operates a semi industrially gold mine at Bétaré Oya and Bindiba/Garoua Boulaï in the East region of Cameroon. In the same token, it also has a third exploitation permit for gold (small mine) in the locality of Woumbou still in the East region. In fact, based on some earlier reports by $\mathrm{C} \& \mathrm{~K}$ Mining Inc., indicating that the diamond reserve potentials of the Mobilong field were estimated at 736 million carats ${ }^{49}$ contrariwise, in other declarations, the reserves were estimated at 420 million carats, which is still more than three times the annual world diamond production in 2009.

Paradoxically, it should be highlighted that even the government of Cameroon does not readily have a clear and consistent information on the exact diamond reserves in Mobilong. Thus, concerning the conglomeratic part, the Decree granting the Mobilong diamond exploitation permit specified that the construction of the mine should start in $2011^{50}$, but however, much still need to be done. This situation has led the project to be given the status of a 'preparatory phase' to industrial exploitation. In sum, it is observed that the various ways that Cameroon can benefit from the exploitation of its mineral resources is to ensure compliance by the mining companies with the various legal, economic, environmental and social obligations. Contrariwise, it is realized that the mining sector on average, has contributed from 2009 to 2011 , just about $1.5 \%$ of the revenues from the extractive sector ${ }^{51}$ in Cameroon; where fiscal obligations are the main source of revenue collection of the State. In this regard, the policy reforms put forth

${ }^{41}$ See CIMEC (2010)., op cit.

${ }^{42}$ See CAPAM (2013)., op cit.

${ }^{43}$ See Law No. 2001/001 of 16 April 2001, establishing the Mining Code as amended by Law No. 2010/011 of July 29 2010, furthering and encouraging the exploration and exploitation of mineral resources necessary for economic and social development as well as poverty alleviation.

${ }^{44}$ Consult the website of the Cameroon International Mining Conference and Exhibition (CIMEC)

${ }^{45}$ The company holds an exploitation permit issued in 2010 by Decree $n^{\circ} 2010 / 374$ of 16 December 2010 on the establishment of a valid exploitation permit for diamond mining and related substances after an exploration permit Order $n^{\circ}$ 024/MINIMDT/SG/DMG/SDAM of April 26, 2006.

${ }^{46}$ According to Article 6 of the Mining Agreement signed between the Republic of Cameroon and C\&K Mining Inc.

${ }^{47}$ Koko Enterprise Co., Ltd is a Korean based company involved in the entertainment and leisure industry. This company was founded in 1990 and its headquarters are in Seoul, Korea

48 See Article 3 of the Decree on the establishment of the mining permit; also see the Agreement signed between C\&K Mining and the State of Cameroon.

${ }^{49}$ Le Secteur Minier Camerounais, EITI Cameroon website

${ }^{50}$ According to Article 6 of the said Decree signed on 16 December, 2010, C\&K has the obligation to begin works within one year from the issue date of the exploitation permit.

${ }^{51}$ According to the EITI Cameroon 2009, 2010 and 2011 reports, the mining sector contributed to 2\%, 2\% and $1 \%$ respectively, to the country's extractive revenues. 
by the Mining Code as amended and other best practices of LCIs could readily enhance and promote the benefits of the government and the affected local communities, by directly and indirectly improving the living standards of the local residents through, notably employment and skills transfer. From this perspective, this section provides an overview of the economic and social aspects relating to local content in the mining sector in Cameroon and its application and constrains as envisaged in the Mobilong diamond exploitation project. In this light, it assesses in turn: the legal provisions of mining activities relating to LCIs as applied in the Mobilong diamond exploitation project, the monitoring modalities and constraints of LCIs, and the provision of recommendations and way forward.

\section{Trends of local content initiatives under the mining sector in Cameroon}

Aptly, within the Cameroon's mining sector laws, the concept of local content ${ }^{52}$ is relatively new, and has not been explicitly provided. Hence, as far as the mining legislation are concerned, local content issues can only be tacitly inferred from them (as shall be considered in the analysis that follows), even though this might be perilous since even the express articulation and respect of local content is still seriously problematic. ${ }^{53}$ In this perspective, to understand the content and scope of LCIs within the Cameroonian context, the following salient facts need to be recapitulated. In the economic perception, local content is akin to 'local added value'. Similarly, the Cameroonian Gas Code defines local content as "All the activities focused on local capacity development, the use of local human and material resources, technology transfer, the use of industrial companies and local services, and the creation of additional values measurable to the local economy". ${ }^{54}$ From this, it is realised that it seems to reconcile the different previous definitional approaches of local content. Consequently, the various components of local content can be sum-up as the use of local labour force together with capacity building (technology transfer) by the company and its partners as well; the use of local industries, services and subcontracting; and finally, the funding of local development projects.

However, the crucial question then is, to what extent and field can local content cover in Cameroon? In this regard, any analysis of LCIs can be considered using the following two approaches. With the first approach considering the local as the "community" where the company is located, and the second considering it as the "nation". In the same token, as earlier reiterated, the approach of local content adopted for this paper, is the one whose components focuses on employment, training, capacity building, suppliers and subcontractors, participation of the company in social projects and local added value, in the national territory with great focus on the immediate local communities where the impact is felt. In this perspective, an analysis of the application of LCIs in the case of the Mobilong diamond exploitation project will provide a big picture on how LCIs are appreciated in the Cameroonian mining context. By doing so, it considers the various actors involve in the monitoring process and the legal provisions of LCIs applicable.

Explicitly, the LCIs requirements and obligations of mining companies in Cameroon can be assessed and analysed using two prime mechanisms. On the one hand, we have the actors - who are involved in the day-to-day monitoring of the implementation of the obligations. With the two main groups of actors that actually do the monitoring of the social obligations of mining companies being those in the public sector and the civil society organizations (CSOs). These actors in the public sector ${ }^{55}$ are generally involved in the control of the mining projects, through the Ministry of Mines, Industry and Technological Development (MINMIDT). Equally, MINMIDT works in close coordination with other administrative departments of its regional offices and other ministries in monitoring the local content obligations. Similarly, many national and international CSOs, like NGOs, are also committed and involved in monitoring the social obligations of mining companies. On the other hand, and more pertinently, we have the key legal framework put in place to that effect, outlining the social obligations of the mining companies. With the 2001 Mining Code as amended together with its text of application, and the 1992 Labour Code in Cameroon being

\footnotetext{
${ }^{52}$ Local Content in general, may be defined in the sense of local participation. It could also be defined as "the level of social adherence in the form participation in, and funding of local projects", i.e., the support of local people through training and capacity building of employees and/or non-employees of the company.

${ }^{53}$ Ses Tamasang, (2016)., op cit., p. 16.

${ }^{54}$ See Article 2 of the Law issued in the 1st ordinary session of March of the 2012 legislative year

${ }^{55}$ See Article 101 of the Mining Code, clearly specifies the supervision role of mining engineers, civil servants and public agents of the Department of Mines and Geology, at the moment divided into two departments, as well as agents of tax and customs administration commissioned to this effect.
} 
paramount. ${ }^{56}$ Indeed, the provision of Article 16(1) of the Mining Code as amended is very resounding as it brings to lamplight the issue of LCIs, within the framework of any mining agreement signed between the government of Cameroon and a mining company. By explicitly stating that "For the development and exploitation of a mineral discovery or for its funding, a mining agreement is concluded between the holder of an exploration permit and the State. The said agreement includes provisions on obligations relating to employment, vocational training and social achievements; relationships with suppliers and subcontractors; (New) the percentage of the production of minerals extracted to devote to local transformation. This percentage cannot be less than fifteen percent (15\%). Any other matter that the parties to the agreement may find of interest".

Consequently, having a close look at the above article, it is observed that the requirements of local processing, source of employment and wealth creation at the local level, are paramount issues to be considered in any Agreement. This also involves the transfer of skills and capacity building, and equally the production-marketing chain in which suppliers and sub-contractors are involved in the process. Similarly, Articles 65 and 128 of the Text of Application of the Mining Code ${ }^{57}$, also contain provisions relating to the obligations of the mining companies in terms of Local Content. In this regard, Article 65 (2) states that "The application for the award of an exploitation permit is addressed and compiled with the Minister of Mines before the expiration date of the exploration permit from which it is derived. The period for which the exploitation permit is requested and accompanied by a feasibility study, including notably: $(f)$ a note on the socio-economic impact of the project, on local residents in particular; $(k)$ proposals of the applicant on the recruitment and training of Cameroonians". Correspondingly, Article 128 provides more emphasis to the above provision by stating that "During the exploitation phase, the management plan describes the management of impacts due amongst others to the following: [...] eventually positive social impacts such as jobs, training opportunities and the provision of communications and infrastructure". Indeed, from these provisions, it is realised that both the Mining Code as amended and its text of application have tacitly illuminated in some way, the notion of LCIs in the Cameroonian context. Conversely, it is worth noting that despite these initiatives, in practical terms, the concept of local content is still embryonic and lagging behind in terms of its integration and implementation in enhancing the socio-cultural welfare of the affected people in Cameroon.

\section{Appraisal of local content initiatives in the Mobilong Project}

Actually, as reiterated above, most literature on the exploitation of natural resources in Cameroon continues to confirm the mineral potential of the country. With the indicator ratio of the explored surface, estimated to about $40 \%$ of the country, of the occurrence and variety of resources found, reflecting this. The context is still clear because mining in Cameroon is still at its early stage. Thus, for the national economy, it could be a factor of growth while for the local economies of the mining sites, it is an opportunity for a development boom, notably with the construction of social infrastructure, consultation with local communities and the practice of "local content" ${ }^{, 58}$. Contrariwise, these economic forecasts do not refute the many environmental impacts of which mining is a source, such as, the destruction of the forest ecosystems, the contamination of the soil, water and air, the destruction of biodiversity, noise pollution, and so on. In this regard, in Yokadouma - where the Cameroon and Korea Mining Incorporation (C\&K Mining Inc.) has been granted permit No. 36 for the exploitation of the Mobilong diamond - is subject to these impacts. In fact, it is observed that the town has not benefited from the industrial exploitation of its forest resources, and thus expects much from the Mobilong diamond project. Consequently, a crucial evaluation of the impacts of the project on its local communities, found that from the Mining Agreement signed between the government of Cameroon and the Korea Mining company in 2010, the fiscal provisions largely favours the company with some related benefits to the local communities. The prime reason for this might be to attract Foreign Direct Investment (FDI). In this case, so many tax exemptions are granted to the company in line with Article 24 of the Mining Agreement, in addition to the 'Tax and Customs' arrangements applicable in the preparatory phase" as far as industrial exploitation is concerned ${ }^{59}$.

\footnotetext{
${ }^{56}$ See Law $n^{\circ}$ 001-2001 of $16^{\text {th }}$ April 2001, establishing the Mining Code and its 2010 amendment together with its text of application - Law $n^{\circ} 2002 / 848$ PM of $26^{\text {th }}$ March 2002, and also Law $n^{\circ} 92-007$ of $14^{\text {th }}$ August 1992 , establishing the Labour Code in Cameroon.

${ }^{57}$ See Decree No. 2002/648/PM of March 26, 2002 - laying down detailed rules for the application of Law No. 001 of 16 April 2001 on the Mining Code

58 'Local content meaning the fraction of local goods and services (labour, sub-contracting and local supply, local participation, skills transfer, etc...) used by the mining company for local development.

${ }^{59}$ These exemptions relate in particular to patent, Value Added Tax, corporate tax, tax on industrial profits, Proportional Taxes on Income from Capital (TPRCM), special tax on salaries paid abroad, Rights of registration
} 
Besides, in addition to the tax obligations of the company, Article 89 of the Mining Code as amended and Article 144 of the Text of Application of the Mining Code, contain provisions on the compensation of the local population for the impacts of the mining project, with right to taxes, proportionately to the value of the products extracted respectively. These include an Ad Valorem tax of 8\% in the case of diamond. Similarly, Article 137 of the Text of Application also provides that local communities and municipalities are entitled to $10 \%$ and $15 \%$ respectively of the tax. In this regard, the question to ponder with is whether these tax provisions are readily implemented, especially as seen in the case of the first exploitation of 617 carats of diamonds in January 2013. Indeed, deductions and observations made within the seven villages ${ }^{60}$ along the mine and the town of Yokadouma, revealed that no payment has been received by them. In the same token, although the obligations relating to the Kimberley Process were met ${ }^{61}$, transfers at the local level have not yet been made. Equally, it is observed that the main cause of the non-transferability of the mining royalties to the local communities, is particularly due to the non-existence of a Joint Order, signed between the Minister in charge of Mines (MINMIDT) and the Minister of Finance (MINFI), as provided for in Article 137 (2) of the Text of Application of the Mining Code.

Pertinently, it is worth noting that despite the legal provisions put in place, it is clear from the brief analysis of the obligations of C\&K Mining Inc. that at the local level, Yokadouma is still to benefit from the tax benefits, social infrastructure development, local content and community consultation from the Mobilong diamond project. Similarly, the needs requested by the people, such as electricity, schools with teachers present, hospitals with doctors' present, an antenna for telecommunications, sports facilities, and so on, are highly perceptible obligations of C\&K Mining Inc. as enshrined in the provisions of the Decree granting the Mobilong exploitation mining permit ${ }^{62}$. Affirmatively, it should be highlighted that the notion of local content is tacitly embedded in the provisions of the Mining code as amended and the Text of Application, the Mining Agreement signed between the government and the Korea Mining company, and the Environmental and Social Management Plan (ESMP) of the company, contained in its 2010 Environmental Action Plan.

In this regard, the provisions of Articles 7, 8, 15(8) and 18(2) of the Mining Agreement are very resounding as they addressed the issues relating to LCIs. With Article 7 stating that "C\&K Mining Inc., its affiliates and subcontractors will use as much as possible the services and raw materials from local sources as well as products manufactured in Cameroon as far as these services, raw materials and products will be available at competitive conditions in terms of price, quality, warranties and delivery dates." From this, it is observed that in relation to the subcontractors and affiliates of C\&K Mining Inc., the issue of local content is optional on grounds of trade liberalization and free competition. Similarly, Article 8 on its part brought out some provisions relating to the use of national and local staff, with the goal to promote and protect national labour throughout the exploitation project. By stating that "during the term of the agreement, $\mathrm{C} \& \mathrm{~K}$ Mining Inc. should commit to employ in priority local staff and enable it to have access all jobs related to its professional qualifications. To this end, C\&K Mining Inc. should implement and in consultation with the competent authorities of the State: a training plan and a system of promotion of the staff; respect the laws and regulations of labour in force, particularly in terms of hygiene, safety and health at work, social security and overtime working practices; progressively promote the replacement of expatriate qualified personnel by local staff who have completed the same training and acquired the same experience during employment; practice non-discrimination of any kind - be it based on race, nationality, gender or sex" ${ }^{63}$

Additionally, a critical view of this provision clearly shows that, despite the strong desire to promote the replacement of expatriate staff as enshrined in the provision, it is realised that the performance of such initiatives is very difficult to assess. That is, even if substitutions are made, the issues on the number of initial national and local labour workforce, the replacement rate and frequency of replacement remain uncertain. In the same token, it is observed that C\&K Mining Inc. might include in its contracts with its co-contractors, a similar requirement and a commitment on their part to include the same requirement in their contracts with subcontractors. Thus, from these

relating to mining operations except those relating to leases and rentals, Customs duties with the exception of equipment, and office furniture and cars, and so on.

${ }^{60}$ Mboy 1 Mboy 2, Long, Mobalo, Mparo, Massiembo and Mang

${ }^{61}$ That is, $8 \%$ Ad Valorem Tax - 5,830,495 CFA francs, 2\% of customs duty related to exportation-1,457,630 CFA francs and 2.5\% related to the functioning of the National Secretariat of the Kimberley Process in Cameroon $1,822,030$ FCFA.

${ }^{62}$ See Decree No. 2010/374 of 16 December 2010 on the establishment of a valid mining exploitation permit for diamond and related substances.

${ }^{63}$ See Article 8(1) of the Mining Agreement between C\&K Mining and the State of Cameroon in 2010. 
given situations, it is clear that there are some debilities and lapses to enhance the protection of the national and local workforce. Correspondingly, it is envisaged that in order to remedy the situation, there is need to put in place a well-coordinated and integrated mechanism, to monitor the various components of mineral exploitation in Cameroon in line with international standards. In the same token, Article 15(8) of the Agreement, in corroboration with the provisions of Article 16 of the Mining Code as amended provides that "C\&K Mining Inc. will process fifteen percent (15\%) of the production of diamond extracted in Cameroon. This processing will start from the first year of its conglomerate production". From these endeavours and obligations relative to LCIs in the agreement, it can be observed that there is a consented effort by the State to benefit from the fallout in terms of employment, training, local processing, subcontractors, local affiliates, and local added value, from the exploitation of diamond and related substances in Mobilong.

Moreover, it is worthy to note that the actors equally have the obligation, in accordance with Article 18(2) of the Agreement, to be "committed not to undertake towards $C \& K$ Mining Inc, its affiliates and subcontractors as well as to their staff, any action on labour or social law that could be considered discriminatory against those that would be imposed on companies engaged in similar activities in Cameroon". In this way, the State, therefore, affirms the guarantee that the staffs will not be subjected to any form of discrimination. Similarly, Article 7 of the exploitation permit of C\&K Mining Inc. provides that "During the validity of the exploitation permit, the Company shall make social, sporting, educational and health infrastructures available to the local residents to support their development". Thus, in addition to the local content obligations of C\&K Mining Inc. provided in the previous provisions, the development of local infrastructure is considered primordial.

Furthermore, elements of local content can tacitly be spotted out in reading the identified impacts and method of their internalization in the ESMP. Such initiatives as job creation and access to training opportunities are impacts with direct interaction. Equally, it is observed that except for the local processing (15\%), no other obligation has indicators. Consequently, it is very difficult to assess the effectiveness of such LCIs without indicators. Similarly, although the monitoring mechanisms in terms of employment, vocational training and sub-contracting can be set up, it is realised, however, that if the base data is not significant, the result too will not be reliable. For instance, if the obligations relating to employment, vocational training and social achievements, do not indicate the threshold of local and/or national labour granted in proportion to the total workforce employed by the company, then, it will be very difficult to ascertain the effectiveness of LCI in this context. In sum, it is observed that even though the Mining Code and its Text of Application present some general provisions regarding LCI, the Agreement is slightly more precise about it. Correspondingly, it is worth noting that in the absence of a viable local content legal framework, LCIs in Cameroon is highly dependent on the various Agreements signed between the government and the mining companies. In this perspective, it is crystal clear that the assessment and monitoring of the local content practices of mining companies in Cameroon, is highly reliable on the human resource policy and corporate social responsibility (CSR) programmes and activities of the various companies. This is owing to the fact that there is no viable legal and institutional system of reference in the country in terms of LCIs or CSR. Thus, to fill this lacuna, there is a great need to put in place a sustainable legal framework that will enhance the implementation and monitoring of LCIs in Cameroon, especially in the embattled mining sector.

\section{Analysis of the local content obligations of C\&K Inc. in the Mobilong Project}

Explicitly, to appreciate the local content obligations and practice of C\&K Mining Inc., it is worth considering both its local and national scope on constraints pertaining to employment, training, priority use of local goods and services by affiliates and subcontractors, the participation of the company to local projects and other local added value activities. Thus, with respect to local employment, it is observed that the manpower of C\&K Mining Inc. is grouped into the local, national and foreign staff ${ }^{64}$. However, it is noted that positions of responsibility are mainly entrusted to staff with skills and good mastery of the English language. In this regard, the indigenous people were not initially considered for employment by C\&K Mining Inc., owing to the fact that they lack the requisite skills and communication capabilities, despite the agreement ${ }^{65}$ signed in April 2013 between C\&K Mining Inc. and the Ministry of Employment and Vocational Training (MINEFOP) through the National Employment Fund (FNE), with the aim of ensuring a fair recruitment process nationwide. Nevertheless, due to recent developments and the needs to

${ }^{64}$ With over 100 employees in the company, the foreigners occupy the administrative positions (mostly Koreans (05)) and the expert workforce (mostly South Africans (04)), while the indigenes of the seven surrounding villages account for between $60 \%$ and $63 \%$ of the contractual workforce, which include temporary and seasonal workers.

${ }^{65}$ Read the article« Le FNE ouvre son fichier de chercheurs d'emploi à C\&K Mining et Justin Sugar Mills » in the May 2013 edition $-\mathrm{n}^{\circ} 14$ of the daily Investir au Cameroun. p. 16 
implement the local content obligations, raised by various stakeholders, C\&K Mining Inc. has proceeded to employ local labour. Besides, apart from the local content requirements, the issue of health and safety of workers are also major concerns for the C\&K Mining Inc. Indeed, it is observed that the working conditions in the Mobilong project are falling short with respect to the necessary requirements in terms of mineral exploitation. ${ }^{66}$ For instance, the workers do not use Personal Protective Equipment (PPE), which meet international standards and they do not have adequate medical coverage. Similarly, the safety device inside the site is almost non-existent, which increases the risk of accident. ${ }^{67}$

Apparently, it is worth noting that even though Cameroon is a member of the ILO, it has not yet ratified most of its conventions $^{68}$, whose purposes are to ensure the social protection of workers and to safeguard fundamental human rights in the mineral exploitation sector. Conversely, despite the fact that the mining sector is undoubtedly embodied with many risks to the health of workers; issues on health and safety of workers in the mining sites are not sufficiently taken into account in the legal framework governing employment issues in Cameroon. Consequently, with the major political development in the mining sector, the revision of the Cameroonian Labour Code ${ }^{69}$ is considered very instrumental as it provides the safety nets to the mining workers and those who intend to work in the mines. In addition, concerning the transfer of skills, it is observed that capacity building is an essential element of local content. It is worth accentuating that a project can only be beneficial to the local community, if it can continue the said activity or those related to it. Thus, with respect to C\&K Inc., it is appreciated that the company has provided training to the local employees on certain working techniques specific to the mining industry and on how to drive their heavy engine vehicles. In spite of this, the 'hard nut to crack' still lies with the nature, criteria of selection for training and the sustainability of the acquired skills after the training. Most importantly, it is realized that the issue of community consultations by the mining company with the traditional and administrative leaders (councilors), and the local population is very essential for the sustainability of any project. In this regard, it is observed that C\&K Inc. did not properly engaged in consultations with the indigenous people, who felt they were not recognized in the project. Indeed, to achieve project sustainability, the prior, free, consent and informed criteria, will act as a panacea for all the indigenous people, whether Baka or Bantu.

Similarly, it is realised that the main activities of subcontracting are limited to the completion of the environmental and social impact assessment (ESIA), which is done by Soft Business Management Consulting Group, (a Cameroonian consulting firm), based in Yaoundé. In the same token, C\&K is using dynamite supplied by a local subcontractor. However, it is observed that the non-involvement of local suppliers in the construction of the base camp of the company and on the origin of the materials used to build them is something of great concerned. From these, it is worth accentuating that the implementation of local content requirements for subcontracting are insufficient and cannot as such help to create local wealth. Additionally, it is realized that the participation of the company in local projects is not visible on the field due to lack of initiatives in constructing social infrastructure as specified by the mining permit granted for the Mobilong project. This is buttressed by the fact that the administrative and municipal authorities have alluded the existence of the Municipal Development Plan and Book of Grievances written by the municipality and the residents to that effect that needs action. ${ }^{70}$ Correspondingly, the municipal authorities have also questioned the lack of initiatives by the company in local projects. Even though the needs are significant as clearly identified in the locality, the company is trying to resolve the issues to appease the tension within the locality in accordance to the agreement.

In sum, despite the tacit existence of provisions on local content in the Mining Code as amended and its Text of Application, the Labour Code, the Mining Convention, the mining permits and the environmental action plan of C\&K Inc; the implementation of these obligations are proves to be ineffective due to the use of general formulas without a binding character and the absence of clear and measurable indicators, as seen in the cases of local employment, provided in Article 8 (1) of the Agreement stating clearly that during the term of the agreement, C\&K

\footnotetext{
${ }^{66}$ Ibid.

${ }^{67}$ Ibid.

${ }^{68}$ Such as International Labour Organisation (ILO) Convention $\mathrm{n}^{\circ} 31$ limiting the hours of work in the mines (coal mines), ILO Convention $n^{\circ} 124$ concerning the medical examination for fitness of adolescents to work underground in mines, and ILO Convention $\mathrm{n}^{\circ} 176$ concerning safety and health in mines.

${ }^{69}$ See Law n ${ }^{\circ}$ 92-007 of 14 August 1992 establishing the Labour Code

${ }^{70}$ Read the article « Le FNE ouvre son fichier de chercheurs d'emploi à C\&K Mining et Justin Sugar Mills » in the May 2013 edition $-\mathrm{n}^{\circ} 14$ of the daily Investir au Cameroun.
} 
Mining Inc. should be committed to use in priority local staff to enable it to access all jobs related to their professional qualifications; transfer of competences as per Article 8 (1) of the Agreement of C\&K stating that during the term of the agreement, C\&K Mining Inc. should be committed to progressively promoting, the replacement of expatriate personnel by qualified local staff having followed the same training and acquired the same experiences on the job; use preferential products and local suppliers with respect to Article 7 which states that C\&K Mining Inc., its affiliates and subcontractors use as much as possible the services and commodities from local sources as well as products manufactured in Cameroon as far as these services, raw materials and products are available under competitive conditions in terms of price, quality, warranties and delivery times; participation in local development according to Article 7 of the exploitation permit Decree which stipulates that during the validity of the exploitation permit, C\&K Mining Inc. is to put at the disposal of local residents, social, sporting, educational and sanitary infrastructures to enhance their development. Consequently, it is worth noting that specific provisions on LCIs, such as those provided in the 2012 Cameroonian Gas Code, should be developed with a view to give further details on the indicators on the share of community goods and services in mining projects. Equally, it is realized that the international governance initiatives ratified by Cameroon could provide a great impetus to local development if the mining companies can respect and observe their provisions in their socio-economic obligations to the local communities. In this perspective, there is an urgent need for a: (a) greater transparency on the payments and receipts of sub-national revenues in EITI (Extractive Industries Transparency Initiative) reports and the inclusion of payments for subcontractors and affiliates companies; (b) greater involvement of the local population in monitoring the operations within the Kimberley Process and other sustainable legislation and regulations; and (c) greater communication, real supervision by public authorities, civil society organizations and the local population, to avoid "sirens of the resource curse" phenomenon. Conversely, it is worth accentuating that the willingness of the government to make mining a reality in the short term, in view of becoming an emerging country by 2035 does not necessarily match up with local realities or the human, technical and technological national resources, and thus needs more precautions in terms of policy design and implementation.

\section{Conclusion:-}

In this contemporary era, in particular during the commodity price boom, there has been a noticeable shift towards local content requirements in resource-rich countries. Among the explanations was the imperative to increase the benefits of the mining sector to the local economy, beyond the rents and taxes. Indeed, despite the go-slow in commodity prices in this era, few countries have backtracked on these reforms although the implementation of the legal frameworks seems to take more time. Consequently, it is important to assess to what extent LCIs have delivered or not on given expectations. This allows countries to gauge the effectiveness of their policy choices and to demonstrate results. However, in many countries, it is too early to see big transformations, given that those measures are relatively new and that there remain important implementation gaps. Besides, while a number of countries are actively developing a range of LCIs and legislation, a set of best practices is yet to emerge. Thus, the initiatives discussed in this paper offer examples of different design options that need to be considered carefully in the context where they operate. This is because the context in a given country may mean elements that work in that country may not necessary work in another. For instance, national legislation requiring specific targets to be met in areas with small or weak industrial bases and a limited number of skilled workers may lead to economic inefficiency and increased corruption. There is a clear need for more empirical research that answers questions of effectiveness of different LCIs and practices in different contexts; the factors contributing to success; how LCIs can support industrial development in local communities; and how governments can maximize benefits for citizens through the right mix of fiscal arrangements and LCIs. Thus, some aspects of LCIs offer greater certainty. As a growing field of practice, there is a need to build capacity to support, monitor and influence local content development, whether among government, industry, CSOs or donors.

Aptly, the role of key stakeholders in partnerships spanning the public and private sectors in the design, implementation and monitoring of LCIs is imperative. Thus, depending on the context and capacities, many national governments, industries and CSOs are now having different roles in different stages of the initiative. Some of the key elements which these partnerships need to focus on include: active and informed citizen participation in local content planning, implementation and monitoring; transparency and accountability in contracts and bidding processes; and alignment of company activities with government plans. Equally, the incorporation of LCIs into EITI processes could address both varying local contexts and the need to engage the different stakeholders in the consultative processes. Indeed, countries that implement EITI could choose to make local content disclosures part of their EITI reports in ways that address the dynamics in the applicable country. Over time, such disclosures from various countries could shed light on emerging best practices. In addition, to build viable partnerships, policymakers 
could draw on lessons from EITI's innovative multi-stakeholder approach. Thus, bringing all the relevant players together to discuss the goals and challenges of developing local content policies will be a great step toward future progress on the issue. Correspondingly, staying abreast with these emerging international rules and utilizing them to have maximum advantages is one of the greatest challenges and opportunities for developing countries, like Cameroon, seeking to negotiate and promote sustainable development for the long-term benefit of its resource-based economies, environments and peoples. In this regard, in monitoring the implementation of LCIs by mining companies in Cameroon, one would have mixed feelings and mitigated results. For instance, in view of the legal provisions, it is difficult to assess compliance or not of the obligations of local content in the absence of a clearly defined legal and institutional framework in the mining sector.

Explicitly, it has been revealed in this paper that mining companies are taking great advantages of the tax exemptions and lapses in the legal framework, resulting from the poor alignment of the institutional frameworks, to obtain low tax bases and ineffectively implementing the tacit provisions of local content found in legislation, regulations and contractual agreements, as seen in the case of the Mobilong mining project. In this perspective, this research has put forth some recommendations to whistle and advocate for a sustainable legal and institutional framework of local content in Cameroon, in order to ameliorate the debilitating legal and operational regime of LCIs by taking a close consideration of the following critical factors: (i) defining the quantitative, qualitative, reliable and verifiable indicators of local content; (ii) outlining a detailed schedule of the implementation of the local content requirements; (iii) formulating sanctions via a gradual regime of sanctions for non-compliance with local content obligations; strengthening the capacities of the national workforce as well as suppliers and other national service providers on jobs related to mineral exploitation;(iv) involving both the local and indigenous communities in the definition and formulation of the objectives of the local content; (v) creating a commission to monitor and evaluate the execution of the fiscal obligations and local content; (vi) strengthening the capacities of different agents in charge of monitoring the local content and fiscal obligations; (vii) harmonizing the different laws and legal frameworks linking the land tenure issues to mining taxation; (viii) ensuring the respect, or reinforcing penalties already specified in case of non-compliance with the tax obligations by a company; (ix) signing the joint MINFI/MINMIDT orders relating to the establishment of the first commercial production and transfer of the ad valorem tax to local communities and local councils; (x) formulating a tax model for the mining sector, updated and adapted to the local, national and international contexts; (xi) planning for penalties for non-compliance of the development schedule of the mining project as specified by the compliant and valid feasibility study, and the decree establishing the permit; (xii) improving the control system on the execution of extractive contracts by systematically publishing the contracts of the extractive companies in order to enable the CSO and local residents to partake in the control process to ensure the respect of the local content engagements by the company; (xiii) improving on the monitoring of the production processes; (xiv) defining a uniform framework applicable to all mining projects that could also respond to national needs, as well as extending its prospects for a harmonized Mining Code in the CEMAC zone, taking into consideration tax and local content obligations: contract type, harmonized mining code; and (xv) publishing and systematically disseminating contracts/agreements in the mining sector. 